\title{
INFILTRATION OF LEUCOCYTES INTO THE UTERINE LUMEN OF THE GOLDEN HAMSTER DURING THE OESTROUS CYCLE AND FOLLOWING MATING
}

\author{
R. YANAGIMACHI AND M. C. CHANG \\ Worcester Foundation for Experimental Biology, Shrewsbury, \\ Mass., and Department of Biology, Boston University, \\ Boston, Mass., U.S.A.
}

(Received 20th October 1962)

\begin{abstract}
Summary. In the uterine lumen of the unmated golden hamster, the highest number of leucocytes (average 308,000 in one uterine horn) appeared soon after oestrus or at the early stage of metoestrus. Following mating with a fertile male, the highest number of leucocytes (average $1,497,000$ ) was found 12 to $14 \mathrm{hr}$ after mating, i.e. about $6 \mathrm{hr}$ earlier than in the unmated female. The principal cause of the acceleration of leucocyte infiltration following mating is neither the stimulation of the cervix and vagina nor the distension of the uterine wall with fluid, but the presence of semen itself, especially of large numbers of spermatozoa in the uterus. The rapid disappearance of spermatozoa from the uterus on the 1st day following mating is ascribed to the phagocytotic action of leucocytes and drainage through the cervix.
\end{abstract}

\section{INTRODUCTION}

The infiltration of leucocytes into the uterine lumen of rodents occurs at a certain stage of the oestrous cycle. In the rat, for example, it occurs towards the end of the oestrous period (Long \& Evans, 1922; Allen, 1931). In the mouse, the infiltration of leucocytes seems to be stimulated by mating. Austin (1957) found a vast number of leucocytes (about 25 million) in the uterine lumen where they were engulfing spermatozoa at 14 to $18 \mathrm{hr}$ after mating. In the mouse, phagocytosis of spermatozoa is perhaps an important mechanism in the removal of spermatozoa from the uterus. Although the phagocytosis of spermatozoa in the female tract is a general phenomenon (Yochem, 1929; Merton, 1939; Chang, 1956; Bierwolf, 1959; Menge, Tyler \& Casida, 1962), the factors that may affect the invasion of leucocytes are not well understood.

This paper presents data concerning the number of leucocytes in the uterine lumen of female hamsters at various stages of the oestrous cycle and also at various times after mating. A series of tests were undertaken to examine some of the factors that might affect the infiltration of leucocytes into the uterine lumen. 


\section{MATERIALS AND METHODS}

Adult female golden hamsters, weighing from 120 to $150 \mathrm{~g}$, were purchased from a local breeder and kept in an air-conditioned room $\left(20^{\circ} \mathrm{C}\right)$ with artificial light ( 6 a.m. to 6 p.m.) for about 2 weeks before use.

Usually, the female hamster has a 4-day oestrous cycle. On the morning following oestrus, a thick, white, opaque mucus, the so-called 'postoestrous discharge', may be extruded from the vagina by gentle pressure (Orsini, 1961). If a group of females with postoestrous discharge is separated from the colony, most of them will come into heat 3 days later in the evening. In accordance with Orsini (1961), the day the postoestrous discharge was observed was designated as Day 2 ; the subsequent days were designated as Day 3, Day 4 and Day 1. The onset of heat may occur as early as 3 p.m. or as late as 11 p.m. on Day 1 . For the present study, females that came into heat between 7 and 9 p.m. were used. The majority of these females ovulate between 3 and $5 \mathrm{a} . \mathrm{m}$. on the next morning (Harvey, Yanagimachi \& Chang, 1961). Within $2 \mathrm{hr}$ after the onset of heat, a female was allowed to mate with a fertile or a vasectomized male for about $30 \mathrm{~min}$. For the injection of spermatozoa or other fluids into the uterus, oestrous females, within $2 \mathrm{hr}$ after the onset of heat, were anaesthetized with ether and the uterine horns were exposed through a ventral midline incision. Then, $0.15 \mathrm{ml}$ of sperm suspension, seminal vesicle fluid, or Hanks' solution (without glucose and phenol red) was injected into the lumen of each uterine horn near to the cervix by means of a No. 25 gauge hypodermic needle. For the preparation of the sperm suspension, two caudal epididymides were minced in $4 \mathrm{ml}$ of Hanks' solution and the epididymal tissue was removed by a low speed centrifugation. The density of spermatozoa in the suspension was approximately $200,000 / \mathrm{mm}^{3}$. The viscous, transparent fluid in the seminal vesicle of a normal fertile male was collected in a syringe by piercing the wall of the vesicle with a hypodermic needle.

For the estimation of the number of leucocytes in the uterine lumen, females in various stages of the oestrous cycle and those at various hours after mating or surgical treatment were killed and the uteri were exposed through a midline incision. The cervical end of each horn was tightly ligated with a thread and $0.2 \mathrm{ml}$ of $0.8 \% \mathrm{NaCl}$ solution was injected. The distended uterine horn was massaged gently, and the fluid was withdrawn into the syringe as completely as possible. The number of leucocytes was estimated by means of a haemocytometer. When a condensed mass of spermatozoa and leucocytes was recovered from the uteri of mated or surgically inseminated females, the sample was diluted twenty to forty times with $0 \cdot 8 \% \mathrm{NaCl}$ solution for the estimation of spermatozoa and leucocytes.

\section{RESULTS}

Table 1 shows the number of leucocytes in the uterine lumen of unmated females in the various stages of the oestrous cycle. During oestrus, none or only a small number of leucocytes, averaging 500 to 1500 , was recovered. Soon after oestrus or in the early stage of Metoestrus A, a large number of leucocytes, averaging 308,000, appeared in the lumen. In the late Metoestrus $\mathrm{A}$ and in 
Metoestrus B, a much smaller number of leucocytes could be recovered. Thus, it seems that the infiltration of leucocytes into the uterine lumen occurs only at the stage of Metoestrus A.

Table 2 shows the numbers of leucocytes and spermatozoa in the uterine lumen of females mated with fertile males. At 1 to $2 \mathrm{hr}$ after mating, although the uteri were engorged with a vast number of spermatozoa, only a small number of leucocytes, 1000 on the average, was recovered from each horn. At 6 to $8 \mathrm{hr}$ after mating, the uteri were still engorged with spermatozoa and yet the number of leucocytes at this time was still low, averaging 6500 . At 12 to $14 \mathrm{hr}$ after mating, a large number of leucocytes, averaging 1,497,000, was recovered together with many immotile spermatozoa (Pl. 1, Fig. 1). Although many of the spermatozoa were found to be engulfed by leucocytes, there were still large numbers of immotile spermatozoa to which no leucocytes were attached. Pl. 1, Fig. 2 shows a cross-section of the uterus at this stage. Many

TABLE 1

NUMBER OF LEUCOCYTES IN THE UTERINE LUMEN OF UNMATED FEMALE HAMSTERS AT VARIOUS STAGES OF THE OESTROUS CYCLE

\begin{tabular}{|c|c|c|c|c|c|}
\hline Day & $\begin{array}{l}\text { Time } \\
\text { of } \\
\text { day }\end{array}$ & $\begin{array}{l}\text { Hours } \\
\text { after onset } \\
\text { of heat }\end{array}$ & $\begin{array}{c}\text { Stages of } \\
\text { oestrous cycle } \\
(\text { Ward, 1946) }\end{array}$ & $\begin{array}{c}\text { No. } \\
\text { females } \\
\text { used }\end{array}$ & $\begin{array}{c}\text { Leucocytes in one } \\
\text { uterine horn } \\
\text { (mean and range) }\end{array}$ \\
\hline 1 & 9 to 11 p.m. & 0 to 4 & Oestrus & 6 & 500 \\
\hline 2 & 3 to 5 a.m. & 6 to 10 & Oestrus & 6 & $\begin{array}{c}(0 \text { to } 2000) \\
1500 \\
(0 \text { to } 9000)\end{array}$ \\
\hline 2 & 9 to 11 a.m. & 12 to 16 & Oestrus and & 7 & $\begin{array}{c}4300 \\
(0+025000)\end{array}$ \\
\hline 2 & 3 to 5 p.m. & 18 to 22 & Metoestrus A & 8 & $\begin{array}{c}308,000 \\
(72,000 \text { to } 770,000)\end{array}$ \\
\hline 2 & 9 to 11 p.m. & 24 to 28 & Metoestrus A & 6 & $\begin{array}{c}75,600 \\
(11,600 \text { to } 154,000)\end{array}$ \\
\hline 3 & 9 to 11 a.m. & 36 to 40 & Metoestrus A & 6 & $\begin{array}{c}500 \\
(0 \text { to } 1000)\end{array}$ \\
\hline 4 & 9 to 11 a.m. & 60 to 64 & Metoestrus B & 6 & $\begin{array}{c}1000 \\
(0 \text { to } 3500)\end{array}$ \\
\hline
\end{tabular}

leucocytes (mainly polymorphonuclear) were seen passing into the lumen through the endometrium. At 18 to $20 \mathrm{hr}$ after mating, a large number of leucocytes, averaging 299,000, could still be recovered. At this time, all the spermatozoa were found to be engulfed by leucocytes. At 24 to $26 \mathrm{hr}$ after mating, an average of 25,500 leucocytes was recovered, but practically no spermatozoa were found in the lumen at this time. Very few or no leucocytes were found in the uterine lumen at 36 to $38 \mathrm{hr}$ after mating. It appears that the leucocyte infiltration is not instantaneous following the deposition of semen in the uterus but occurs about $10 \mathrm{hr}$ later.

The number of spermatozoa in the uterus decreased rather rapidly on the 1st day following mating. In the vagina, on the other hand, a vast number of dead spermatozoa appeared, indicating that the spermatozoa in the uterus were quickly evacuated into the vagina through the cervix. It seems therefore that two mechanisms, namely phagocytosis by leucocytes and drainage through 


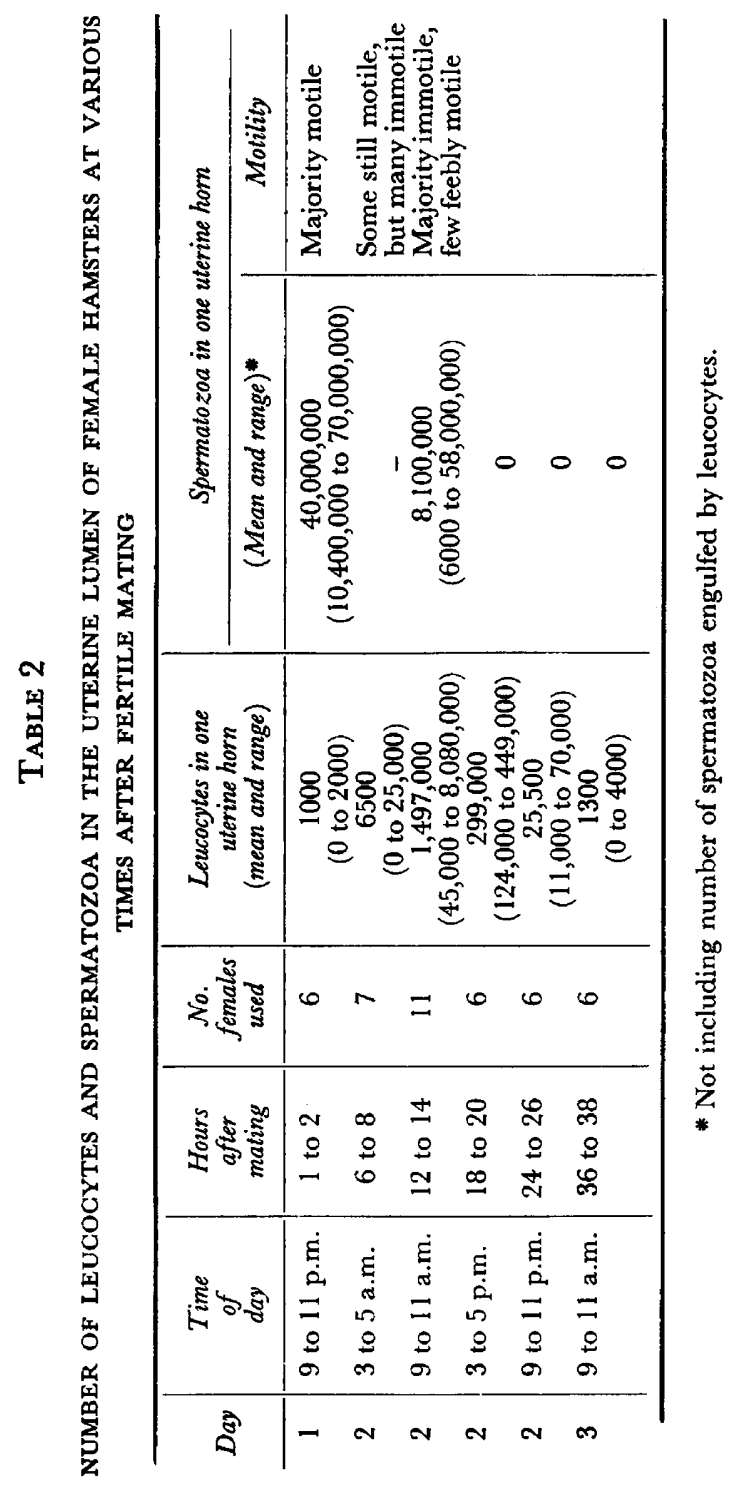


the cervix, are responsible for the rapid disappearance of spermatozoa from the uterine lumen of mated hamsters.

The number of leucocytes appearing in the uteri of the unmated and the mated females is shown graphically in Text-fig. 1. It will be seen that mating accelerated and increased the leucocyte infiltration into the uterine lumen.

Table 3 shows the number of leucocytes recovered from the uteri at 12 to 14 $\mathrm{hr}$ after mating either with fertile or vasectomized males or after surgical treatment. It will be seen that a large number of leucocytes appear following mating either with a fertile male (Test 1 ) or with a vasectomized male (Test 2 ). A smaller, but nevertheless still large number of leucocytes was counted

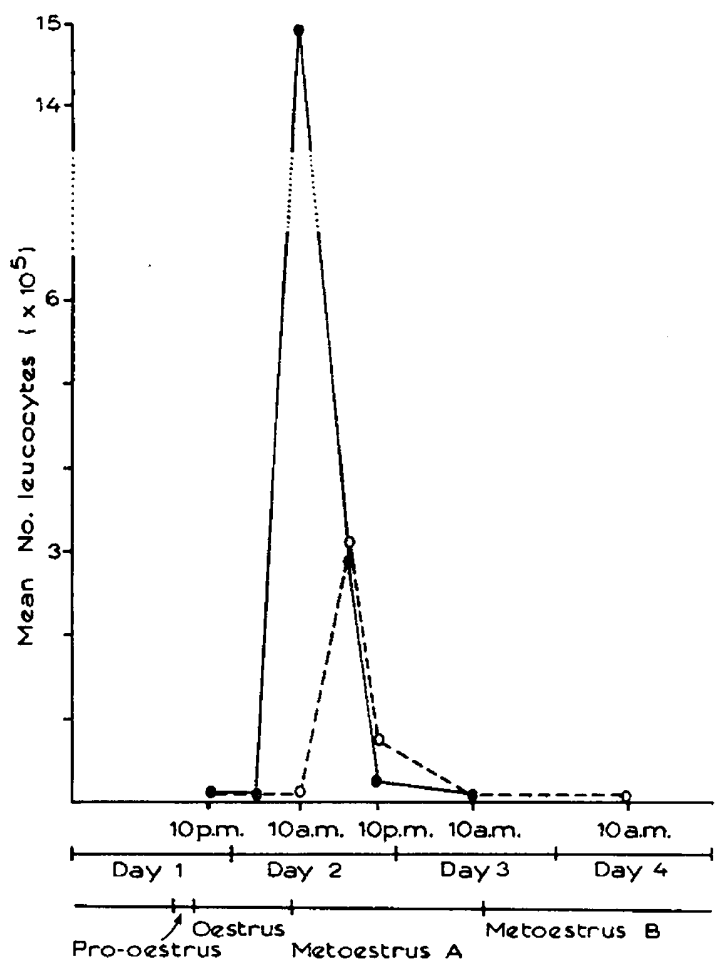

Text-Fig. 1. Number of leucocytes appearing in the uterine lumen of unmated (O) and mated $(\bullet)$ females.

following injection of epididymal sperm suspension (Test 3) or of seminal vesicle fluid (Test 4). It is to be noted that the semen of fertile males induced the highest number of leucocytes while the seminal vesicle fluid (without spermatozoa and fluids of other male accessory glands) induced the lowest number of leucocytes. The leucocyte count was rather low following injection of Hanks' solution (Test 6) or ligation of cervix with thread (Test 7). A prolonged distension of the uterine wall by ligation of the cervical end of the uterus and injection of Hanks' solution into the uterine lumen (Test 5) did not induce the infiltration of a large number of leucocytes, suggesting that the expansion of the uterine wall itself is not a primary cause of the infiltration. 
The leucocyte count was also low following the mating of females whose uteri had been ligated at the cervical ends (Test 8 ). This seems to imply that any stimulus that may be given to the vagina and the cervix during copulation has no marked effect on the leucocyte infiltration.

\section{DISCUSSION}

In the hamster, the infiltration of leucocytes through the uterine endometrium occurs soon after oestrus or at the early stage of metoestrus. This was reported by Ward (1948) and confirmed in our study.

In the hamster, the semen is deposited in the uterus at copulation, as in the

TABLE 3

NUMBER OF LEUCOCYTES RECOVERED FROM ONE UTERINE HORN AT 12 TO 14 HR AFTER MATING, OPERATION AND INJECTION OF FLUIDS INTO THE UTERUS

\begin{tabular}{c|l|c|c}
\hline Test & \multicolumn{1}{|c|}{ Treatment of females } & $\begin{array}{c}\text { No. } \\
\text { females used }\end{array}$ & $\begin{array}{c}\text { No. leucocytes } \\
\text { (mean and range })\end{array}$ \\
\hline 1 & Mated with a fertile male & 7 & $\begin{array}{c}927,300 \\
(61,000 \text { to } 3,580,000)\end{array}$ \\
\hline 2 & Mated with a vasectomized male & 8 & $\begin{array}{c}662,100 \\
(32,000 \text { to } 2,244,000)\end{array}$ \\
\hline 3 & $\begin{array}{l}\text { Injection of epididymal } \\
\text { spermatozoa suspended in Hanks' } \\
\text { solution into the uterus }\end{array}$ & 7 & $\begin{array}{c}436,000 \\
(18,000 \text { to } 2,220,000)\end{array}$ \\
\hline 4 & $\begin{array}{l}\text { Injection of seminal vesicle fluid } \\
\text { into the uterus }\end{array}$ & 7 & $\begin{array}{c}273,000 \\
(9000 \text { to } 990,000)\end{array}$ \\
\hline 5 & $\begin{array}{l}\text { Ligation of the uterus near the } \\
\text { cervix after injection of Hanks' } \\
\text { solution into the uterus }\end{array}$ & 6 & $\begin{array}{c}127,500 \\
(10,000 \text { to } 450,000)\end{array}$ \\
\hline 6 & $\begin{array}{l}\text { Injection of Hanks' solution into } \\
\text { the uterus }\end{array}$ & 7 & $\begin{array}{c}79,500 \\
(7000 \text { to } 258,000)\end{array}$ \\
\hline 7 & $\begin{array}{l}\text { Ligation of the } \\
\text { cervix }\end{array}$ & $\begin{array}{l}47,000 \\
(1000 \text { to } 216,000)\end{array}$ \\
\hline 8 & $\begin{array}{l}\text { Mated with a fertile male after } \\
\text { ligation of the uterus near } \\
\text { the cervix }\end{array}$ & 5 & $\begin{array}{c}12,500 \\
(1000 \text { to } 250,000)\end{array}$ \\
\hline
\end{tabular}

rat (Blandau \& Odor, 1949). The number of leucocytes appearing in the uterine lumen of mated females was much higher than that found in unmated females. Thus, the deposition of semen in the uterus definitely provokes an active infiltration of leucocytes. Austin (1957) examined histological preparations of the uteri of unmated and mated mice at 14 to $16 \mathrm{hr}$ after ovulation and found that the uterine wall of both unmated and mated females contained an equally large number of leucocytes. The passage of leucocytes through the endometrium, however, seems to occur more actively in the mated animal than in the unmated one. Austin considered that the active migration of leucocytes 


\section{PI.ATE 1}



Fis. 1. Spermatozoa and leucocytes recovered from the uterine Iumen of a mated female. About $12 \mathrm{hr}$ after mating. Photographed with a phase-contrast microscope. $(\times 370)$. Fic. 2. A section of uterine endometrium showing leucocytes passing into the lumen. About $12 \mathrm{hr}$ after mating. Fixed in Carnoy; stained with toluidine blue and eosin. $(\times 740)$. 
in the mated animal is mainly due to distension of the uterus with fluid and not to the presence of spermatozoa in the uterus. In the hamster, the distension of the uterus itself cannot be considered as a direct cause of the leucocyte invasion as shown in the present study (Test 5). Both spermatozoa and seminal plasma deposited in the uterus appear to be the primary cause of the active invasion of leucocytes. Since bacterial contamination is a common feature of mammalian semen (Gunsalus, Salisbury \& Willett, 1941; Almquist, Prince \& Reid, 1949), it is possible that bacteria introduced into the uterus following mating either with normal or vasectomized males may cause the leucocyte infiltration to a certain extent, as suggested by the study of McDonald, Black, McNutt \& Casida (1952) on the rabbit.

An important function of leucocytes appearing in the uterine lumen following mating is probably to eliminate dead or unnecessary spermatozoa by phagocytosis. In the mouse and the rabbit, phagocytosis of spermatozoa by leucocytes appears to be very active (Austin, 1957; Bierwolf, 1959; Menge et al., 1962). In the rat, on the other hand, phagocytosis is less extensive (Austin, 1957). Most of the spermatozoa deposited in the rat uterus are evacuated into the vagina through the cervix towards the end of oestrus (Blandau \& Odor, 1949; Austin, 1957). Blandau \& Odor considered that the relatively few spermatozoa remaining in the uterus undergo fragmentation and eventually dissolve in the tract. In the hamster, as observed in the present study, a large proportion of the uterine spermatozoa was evacuated into the vagina near the end or soon after oestrus; most of the spermatozoa left in the uterine lumen were engulfed and destroyed by leucocytes. Thus, the removal of spermatozoa from the hamster uterus is carried out mainly by two mechanisms, drainage through the cervix and phagocytosis by leucocytes.

Recently, many investigators have reported that the uterus of the rabbit during the follicular (oestrous) phase has a stronger bactericidal activity than during the luteal phase (Rowson, Lamming \& Fry, 1953; Black, Simon, Kidder \& Wiltbank, 1954; Hawk, 1959). Broome, Winter, McNutt \& Casida (1960) found that the uterus of the female rabbit produces or releases leucocytes more quickly during the follicular phase than during the luteal phase. The bactericidal activity of the uterus was considered to be closely associated with the infiltration of leucocytes (Hawk, 1958). Hawk, Turner \& Sykes (1960) found that the bactericidal activity of the rabbit uterus is increased by oestrogen and inhibited by progesterone.

One may question whether the phagocytosis of spermatozoa in the uterus is controlled by hormonal factors as is the bactericidal activity of the uterus. Menge et al. (1962) reported that when spermatozoa were injected into the uteri of rabbits during the follicular phase or the luteal phase, the number of spermatozoa recovered 20 to $24 \mathrm{hr}$ after injection was not markedly different, nor was there any great difference in the number of leucocytes recovered from the uterus during the two phases. On the other hand, Chang (1958) has observed that the uteri of immature and ovariectomized rabbits treated with oestrogen released many more leucocytes into the lumen in response to spermatozoa than those treated with progesterone. Further study is required of the uterine response to spermatozoa, bacteria, and other foreign bodies under 
various hormonal conditions. One also wonders whether there are other functions of leucocytes in the uterus, besides elimination of bacteria and spermatozoa.

\section{ACKNOWLEDGMENTS}

This work was supported by grants from U.S. Public Health Service RG-8167 and the Population Council Inc, New York.

\section{REFERENCES}

Allen, W. M. (1931) Cyclic alternations of the endometrium of the rat during the normal cycle, pseudopregnancy and pregnancy. Anat. Rec. 48,65.

Almquist, J. Q., Prince, P. W. \& Reid, J. J. (1949) Bacteriological studies of bovine semen. I. Numbers of bacteria and the relation to fertility. $\mathcal{F}$. Dairy Sci. 32, 543.

Austin, C. R. (1957) Fate of spermatozoa in the uterus of the mouse and rat. F. Endocrin. 14, 335.

BiERwolf, D. (1959) Kurzer Beitrag zur Frage des Schicksals von nicht befruchtenden spermien im weiblichen Genitaltrakt. Biol. Zbl. 78, 823.

Black, W. G., Simon, J., Kidder, H. E. \& Wiltbank, J. N. (1954) Bactericidal activity of the uterus in the rabbit and the cow. Amer. F. vet. Res. 15, 247.

Blandau, R. J. \& OdoR, D. L. (1949) The total number of spermatozoa reaching various segments of the reproductive tract in the female albino rat at intervals after insemination. Anat. Rec. 103, 93.

Broome, A. W., Winter, A. J., McNutt, S. H. \& CAsida, L. E. (1960) Variations in uterine response to experimental infection due to the hormonal state of the ovaries. II. The mobilization of leucocytes and their importance in uterine bactericidal activity. Amer. J. vet. Res. 21, 675.

CHANG, M. C. (1956) Reaction of the uterus on spermatozoa in the rabbit. Ann. Ostet. Ginec. 4, 74.

Chang, M. C. (1958) Capacitation of rabbit spermatozoa in the uterus with special reference to the reproductive phases of the female. Endocrinology, 65, 619 .

Gunsalus, I. C., Salisbury, G. W. \& Willett, E. L. (1941) The bacteriology of bull semen. 7. Dairy Sci. 24, 911.

Harvey, E. B., Yanagimachi, R. \& Chang, M. C. (1961) Onset of estrus and ovulation in the golden hamster. F. exp. Zool. 146, 231.

Hawk, H. W. (1958) The influx of leucocytes and presence of bactericidal substances in inoculated uteri of estrous and pseudopregnant rabbit. F. Anim. Sci. 17, 416.

HAwK, H. W. (1959) Investigations concerning bactericidal substances in rabbit uteri. Amer. J. vet. Res. 20, 206.

Hawk, H. W., Turner, G. D. \& Sykes, J. F. (1960) The effect of ovarian hormones on the uterine defense mechanism during the early stage of induced infection. Amer. F. vet. Res. 21, 644 .

Long, J. A. \& Evans, H. M. (1922) The estrous cycle in the rat and its associated phenomena. Mem. Univ. Calif. 6, 1.

McDonald, L. E., Black, W. G., McNutt, S. H. \& Gasida, L. E. (1952) The response of the rabbit uterus to instillation of semen at different phases of the estrous cycle. Amer. $\mathcal{F}$. vet. Res. 13, 419.

Menge, A. C., Tyler, W. J. \& Casida, L. E. (1962) Factors affecting the removal of spermatozoa from the rabbit uterus. F. Reprod. Fertil. 3, 396.

Merton, H. (1939) Studies on reproduction in the albino mouse. III. The duration of life of spermatozoa in the female reproductive tract. Proc. roy. Soc. Edinb. 59, 207.

Orsins, M. W. (1961) The external vaginal phenomena characterizing the stages of the estrous cycle, pregnancy, pseudopregnancy, lactation, and the anestrous hamster, Mesocricetus auratus Waterhouse. Proc. Anim. Care Panel, 11, 193.

Rowson, L. E., Lamming, G. E. \& Fry, R. M. (1953) The relationship between ovarian hormones and uterine infection. Vet. Rec. 65, 335.

WARD, M. C. (1946) A study of the estrous cycle and the breeding of the golden hamster, Cricetus auratus. Anat. Rec. 94, 139.

WARD, M. C. (1948) The early development and implantation of the golden hamster, Cricetus auratus, and the associated endometrial changes. Amer. 7. Anat. 82, 231.

Yoснем, D. E. (1929) Spermatozoon life in the female reproductive tract of the guinea pig and rat. Biol. Bull., Woods Hole, 56, 274. 